\title{
APPLICATION OF ACCOUNTING DATA FROM ERP SYSTEMS OF BUSINESS ENTITIES IN LOGISTICS
}

The aim of this paper is to introduce the methodology for application of accounting data of ERP systems, gained from business entities in the Czech Republic, in logistics.

Every accounting file provides information about realized sales and purchases of each entity. With the help of accounting data it is possible to determine frequency and value of all sales and purchases. From the known address of the observed entity and its supplier and customer it is possible to derive the delivery distance. This logistic information can be analyzed and evaluated in charts.

Although the result of the examination cannot be fully generalized due to a limited data source, it should be considered as the contribution to logistics studies in the broadest context.

Keywords: Accounting data, Logistics, Enterprise Resource Planning Systems.

\section{Introduction}

This article is intended to be a contribution to the application of ERP (Enterprise Resource Planning) systems of business entities to logistics sciences as a result of a several-year research. The main goal is to demonstrate the potential of using accounting data from ERP systems for logistics evaluation, e.g. for identification of frequency and value of sales and purchases depending on delivery distance. The theoretical framework contains theoretical grounds for application of accounting data from ERP to logistics evaluation. The practical part then deals with identification of frequency and value of sales and purchases depending on the delivery distance, based on accounting data from the years 2007 to 2013 of 30 randomly selected business entities with operation in the Czech Republic regardless business subject classification.

\section{ERP Accounting Data}

Accounting data represent an essential element of each ERP system. They bear the recorded facts related to company activities and are transferable, interpretable and can be processed. They include all the facts of the organization's micro and macro environment like recorded data of economic facts and other factors affecting the chain of the company value chain [1]. The basic function of accounting is to provide all its users with reliable information on the company economic situation. Accounting information is intended for both managers and various external users that are interested in the company for various reasons. We can thus differentiate between two basic groups of accounting information users [2]:

Entities directly involved in company financing (company owners and creditors - e.g. bond holders, banks, suppliers);

Entities that are somehow interested in the company financial results (revenue offices, state administration, employees, competitors, potential investors, the public).

Financial accounting data are formed by the facts in the field of asset situations, receivables from customers, debts to suppliers, and they also monitor incomes and costs from the point of view of the accounting unit as a whole. They include all transactions in the field of purchasing and selling goods, material, own products and services, including the stem data of suppliers and customers [3].

\section{Logistics and Accounting Data}

Today logistic firms need to provide information to their vendors and customers. Resources for processing complex information and communication are required in the business world to assist global logistics. It is very important to plan

\footnotetext{
* ${ }^{1}$ Petr Hanzal, ${ }^{2}$ Roland Beranek

'Department of Applied Mathematics and Informatics, Faculty of Economics, University of South Bohemia, Ceske Budejovice, Czech Republic 2BMD Akademie, Steyr, Austrian Republic

E-mail: phanzal@ef.jcu.cz
} 
a framework to manage materials, services, information and also capital flows of business. To increase the productivity of providing goods and/or services to the clients in Supply Chain Management (SCM) system, planning, organizing and managing activities become a vital issue [4]. It is believed that adoption of new technologies, especially information technologies, not only improves operating efficiencies, but also generates competitive advantage in logistics industry [5].

Effective operations of enterprises in almost every sectors of the economy require a well- functioning transport. It plays a very important role in logistics, because of the goods movement and the creation of ancillary services. In the past, the former economic information systems in the enterprises were used very marginally due to lack of competition. Currently, at the market there are a lot of competing firms, which led to invent new technologies and techniques [6]. The role of information systems in logistics increased. Organizing and managing information flows is done mostly using electronics means, both with the same company and between it and companies in upstream and downstream supply chain. In this way large volumes of data can be analyzed and effective and efficient decision can be taken, saving time and costs [7]. Information systems and knowledge flows play a decisive role in confirming the knowledge based economy as belonging to contemporary reality, both as a determinant of professional and managerial activities, as well as a scientific research object [8].

Economists' interest in activities and mutual transactions of companies, also from the point of view of locations where the companies are based, is very important [9]. The networked economy is, besides customer expectation, cost pressure, globalization, one of the main trends of logistics and supply chain management today and in the future [10]. Allocation of resources and selection of a suitable place for a particular activity is a strategic question for each business entity [11]. Individual authors approach its solution with accent to different factors - foreign investments [12] and [13], cluster evolution [14], urbanization aspects [15], etc.

Economies with high agglomeration rates are those external economies, where a company localized at the same place as more companies can benefit from them. This factor is traditionally supported by the two following mechanisms. At first, it is a reduction of operating costs with the possibility to share certain social and physical infrastructure resources, and secondly, it is the reduction of transport cost as a result of extended interaction between suppliers and customers that are located next to each other [11] and [16]. Economy of scale is the basic component of all models emphasizing the role of diversity of outputs and inputs. Companies having the possibility for a higher degree of economies of scale are looking for functional regions with high market potential where they can exploit their advantage. Some types of goods and services are connected with high geographic transaction costs, which determine whether production in the region will or will not be profitable. This is why products should be classified with regard to their sensitivity in relation to transaction costs. Specific product categories with development potential in small or medium or large functional regions may be defined based on this approach [16] and [17].

Figure 1 illustrates schematically the network of business entities and their suppliers and customers. Entities $E_{1}$ up to $E_{i}$ represent the investigated business entities whose accounting data are available. $S_{1}$ up to $S_{j}$ are the suppliers of the entities $E_{1}$ up to $\mathrm{E}_{\mathrm{i}} \cdot \mathrm{C}_{1}$ up to $\mathrm{C}_{\mathrm{k}}$ are the customers of the entities $\mathrm{E}_{1}$ up to $\mathrm{E}_{\mathrm{i}}$. The value and number of sales of goods, own products and services to the customer $\mathrm{C}_{1}, \mathrm{C}_{2}$, whose address is saved in accounting master data of entity $\mathrm{E}_{1}, \mathrm{E}_{2}$ can be traced by means of accounting data of entity $E_{1}, E_{2}$. Similarly, the value and number of purchase of material, goods and services from supplier $\mathrm{S}_{1}, \mathrm{~S}_{2}$, whose address is saved in accounting master data of entity $\mathrm{E}_{1}, \mathrm{E}_{2}$, can be traced by means of accounting data of entity $\mathrm{E}_{1}, \mathrm{E}_{2}$.

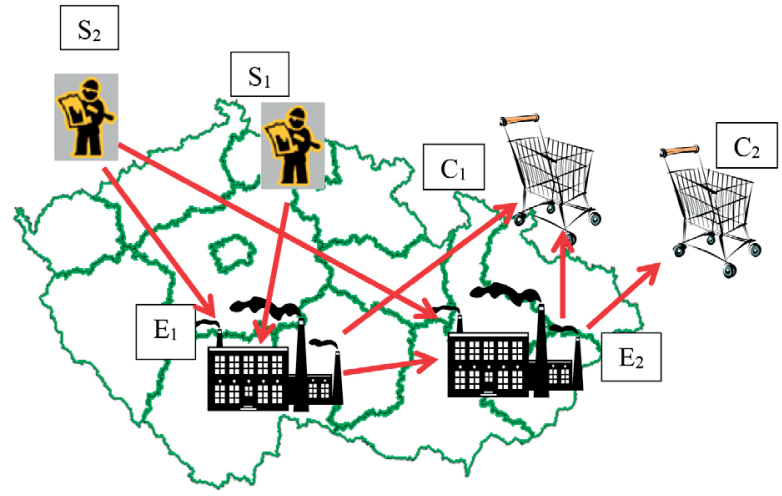

Fig. 1 The network of business entities and their customers and supplier - own source

The supplier's and customers' master data contain information on the registered office and postal code from which not just jurisdiction to the region but also geodetic geographic width and length can be deduced.

Therefore, it can be stated that the corporations accounting data are not only the bearers of information on time as well as on spatial arrangement of business transactions they record. It implies also the fact that corporate information systems' accounting data can be used for logistics statistics.

\section{Methodology of Work}

These partial goals were defined for fulfilment of the main goal:

Definition of an indicator of intensity of economic relations based on business cases of business entities, which will be used in the next part of the work;

Demonstration of the possibility to identify dependencies upon ERP accounting data from selected business entities. 
Definitions, calculation and data sources of the individual items (own source)

Table 1

\begin{tabular}{|c|c|c|c|c|}
\hline Intensity & $\begin{array}{l}\text { Mathematical } \\
\text { definition }\end{array}$ & Description of variables & Data filter criteria & Unit \\
\hline $\begin{array}{c}I_{h p z} \\
\text { Intensity of the values of sales of } \\
\text { goods \& own products for delivery } \\
\text { distance } d\end{array}$ & $\frac{1}{n} \sum_{i=1}^{n} \frac{B_{i}}{Y_{i}}$ & $\begin{array}{c}B_{i}-\text { total value of all sales of goods \& } \\
\text { own products by business entity } i \text { for } \\
\text { delivery distance } d\end{array}$ & $\begin{array}{l}\text { Synthetic account } \\
604 \text { for goods } \\
601 \text { for own products }\end{array}$ & $\begin{array}{c}\text { CZK / } \\
\text { employee }\end{array}$ \\
\hline $\begin{array}{l}I_{p p z} \\
\text { Intensity of the number of sales of } \\
\text { goods \& own products for delivery } \\
\text { distance } d\end{array}$ & $\frac{1}{n} \sum_{i=1}^{n} \frac{C_{i}}{Y_{i}}$ & $\begin{array}{l}C_{i} \text { - total number of all sales of goods } \\
\& \text { own products to target distance by } \\
\text { business entity } i \text { for delivery distance } d\end{array}$ & $\begin{array}{l}\text { Synthetic account } \\
604 \text { for goods } \\
601 \text { for own products }\end{array}$ & $\begin{array}{l}\text { Number / } \\
\text { employee }\end{array}$ \\
\hline $\begin{array}{c}I_{h p s} \\
\text { Intensity of the values of sales of } \\
\text { services for delivery distance } d\end{array}$ & $\frac{1}{n} \sum_{i=1}^{n} \frac{D_{i}}{Y_{i}}$ & $\begin{array}{c}D_{i} \text { - total value of all sales of services } \\
\text { to target distance by business entity } \\
i \text { for delivery distance } d\end{array}$ & $\begin{array}{l}\text { Synthetic account } \\
602 \text { for services }\end{array}$ & $\begin{array}{c}\text { CZK / } \\
\text { employee }\end{array}$ \\
\hline $\begin{array}{c}I_{p p s} \\
\text { Intensity of the number of sales of } \\
\text { services for delivery distance } d\end{array}$ & $\frac{1}{n} \sum_{i=1}^{n} \frac{E_{i}}{Y_{i}}$ & $\begin{array}{l}E_{i} \text { - total number of all sales of } \\
\text { services to target distance by business } \\
\text { entity } i \text { for delivery distance } d\end{array}$ & $\begin{array}{l}\text { Synthetic account } \\
602 \text { for services }\end{array}$ & $\begin{array}{l}\text { Number / } \\
\text { employee }\end{array}$ \\
\hline $\begin{array}{c}I_{h n z} \\
\text { Intensity of the values of purchases } \\
\text { of goods \& material for delivery } \\
\text { distance } d\end{array}$ & $\frac{1}{n} \sum_{i=1}^{n} \frac{F_{i}}{Y_{i}}$ & $\begin{array}{c}F_{i} \text { - total value of all purchases of } \\
\text { goods \& material from source distance } \\
\text { by business entity } i \text { for delivery } \\
\text { distance } d\end{array}$ & $\begin{array}{l}\text { Synthetic account } \\
131 \text { for goods } \\
111 \text { for material }\end{array}$ & $\begin{array}{c}\text { CZK / } \\
\text { employee }\end{array}$ \\
\hline $\begin{array}{c}I_{p n z} \\
\text { Intensity of the number of } \\
\text { purchases of goods \& material for } \\
\text { delivery distance } d\end{array}$ & $\frac{1}{n} \sum_{i=1}^{n} \frac{G_{i}}{Y_{i}}$ & $\begin{array}{c}G_{i}-\text { total number of all purchases of } \\
\text { goods \& material from source distance } \\
\text { by business entity } i \text { for delivery } \\
\text { distance } d\end{array}$ & $\begin{array}{l}\text { Synthetic account } \\
131 \text { for goods } \\
111 \text { for material }\end{array}$ & $\begin{array}{l}\text { Number / } \\
\text { employee }\end{array}$ \\
\hline $\begin{array}{c}I_{\text {hns }} \\
\text { Intensity of the values of purchases } \\
\text { of services for delivery distance } d\end{array}$ & $\frac{1}{n} \sum_{i=1}^{n} \frac{H_{i}}{Y_{i}}$ & $\begin{array}{c}H_{i} \text { - total value of purchases of } \\
\text { services from source distance by } \\
\text { business entity } i \text { for delivery distance } d\end{array}$ & $\begin{array}{l}\text { Synthetic account } \\
518 \text { for services }\end{array}$ & $\begin{array}{c}\text { CZK / } \\
\text { employee }\end{array}$ \\
\hline $\begin{array}{c}I_{p n s} \\
\text { Intensity of the number of } \\
\text { purchases of services for delivery } \\
\text { distance } d\end{array}$ & $\frac{1}{n} \sum_{i=1}^{n} \frac{I_{i}}{Y_{i}}$ & $\begin{array}{l}I_{i} \text { - total number of sales of services } \\
\text { from source distance by business entity } \\
i \text { for delivery distance } d\end{array}$ & $\begin{array}{l}\text { Synthetic account } \\
518 \text { for services }\end{array}$ & $\begin{array}{l}\text { Number / } \\
\text { employee }\end{array}$ \\
\hline
\end{tabular}

\section{Methods Applied to the Research of dependencies}

The indicators of intensity of economic relations based on business cases of business entities were defined, which characterizes the situation in mutual transaction from the viewpoint of purchases and sales of goods, own products and services transacted in the monitored business units. They were calculated from a sample of accounting data, gained from 30 randomly selected business entities with countrywide operation, from 2007 to 2013.

Transaction dependencies were localized by means of a coordinated approach where the above indicator of intensity of economic relations based on business cases of business entities was calculated for each distance, leading to identification of relations.

\section{Indicators of Intensity of Economic Relations Based on Business Cases of Business Entities Dependent on Delivery Distance}

The indicators were designed as an annual average value or the average annual number of sales / purchases all considered entities per employee, depending on the sale / purchase distance carried.

The definition itself, calculation and data sources of the individual partial intensities are summarized in Table 1, while the meanings of the individual variables are as follows:

- number of employees in a business entity $i$, where $i=1 \ldots$.

- number of business entities (here 30 ).

- delivery distance. 


\section{Research Input Data Sources}

\section{Database of Business Entities}

A set of 30 randomly selected unnamed monitored entities from the Czech Republic with countrywide operation regardless the business subject (NACE) is the primary data source. All the involved business entities were monoregional, i.e., all their units were located in the same place as the administration unit.

\section{Database of Accounting Cases}

Consolidated accounting file for the years 2007-2013, containing 4,35 million sentences, is the key data source for the research. Each accounting case includes the following information:

Account number, CREDIT and DEBIT sides, date and number of a document, accounting period, customer/supplier number, accounting text information, document symbol and a code specifying to which of the 30 monitored business entities each transaction belongs.

Supplier accounting cases may be chosen easily by means of the CREDIT side of synthetic account 321 - trade payables. The following prevailing main types of transactions may be distinguished by synthetic classification of accounts on the DEBIT side:

111 - cost of material (or also 112), 131 - cost of merchandise (or also 132), 518 - rendered services.

Customer accounting cases may be chosen by means of the DEBIT side of synthetic account 311 - trade receivables. The following prevailing primary types of transactions may be distinguished by accounting synthesis of the given operation on the CREDIT side:

601 - manufactured goods revenue, 602 - service revenue, 604 - merchandise goods revenue.

\section{Database of Customers and Suppliers}

A data file of 27,900 items of legal entities and individuals, each with the number and address of the customer/supplier, country and post code, was gained by combining lists of customers and suppliers of all the 30 monitored business entities.

\section{Results}

In following Figs. 2 - 9 are illustrated research results.

The curves of sale and purchase values and numbers of goods and services supplied, depending on the delivery distance, have almost regularly repeating similar shape.
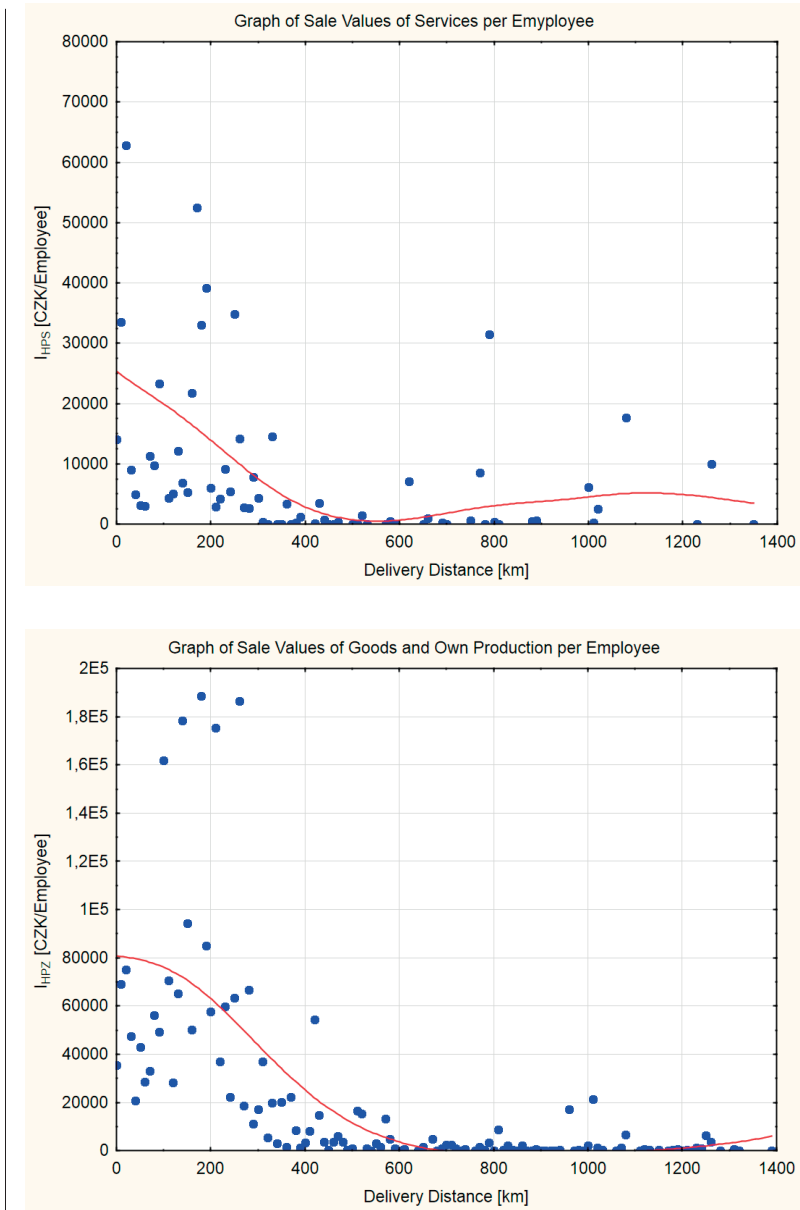

Figs. 2 and 3 Graph of sales values of services per employee and year and goods and own production per employee and year (own source)

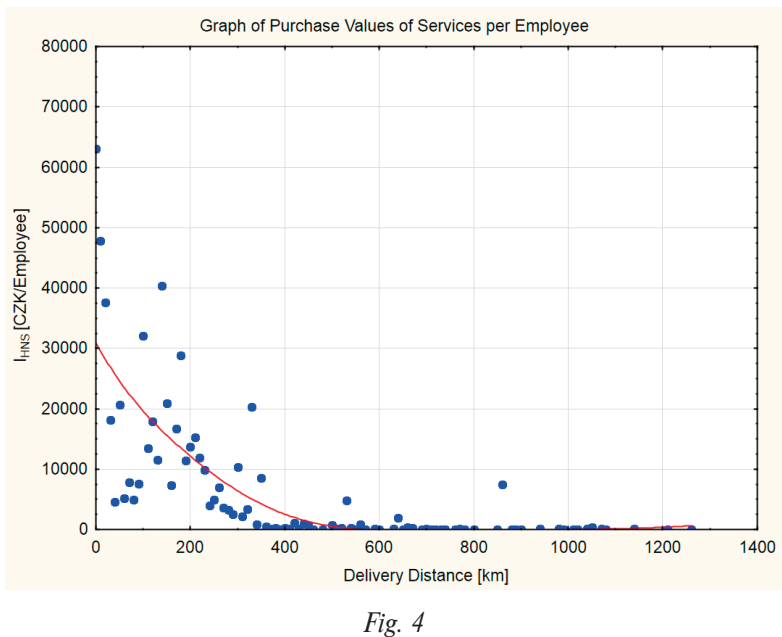

Fig. 4 


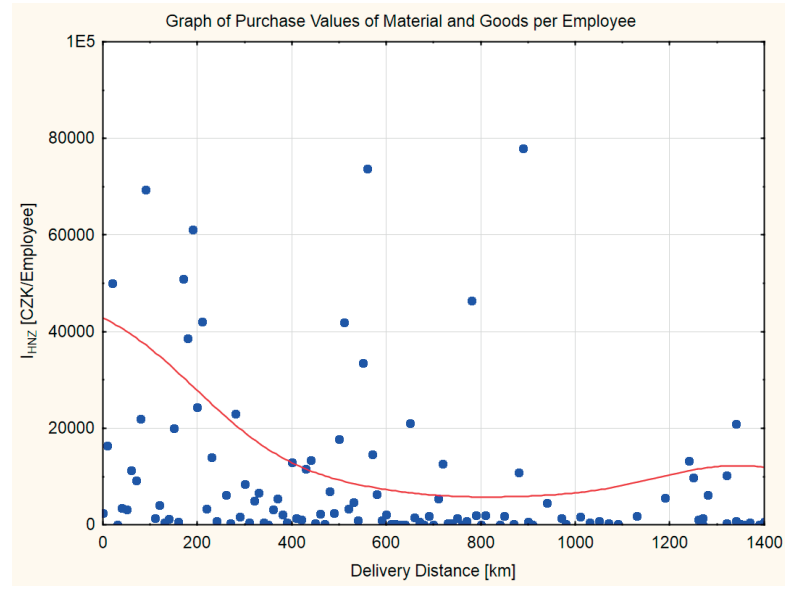

Fig. 4 and 5 Graph of purchase values of services per employee and year and purchase values of material and goods per employee and year (own source)
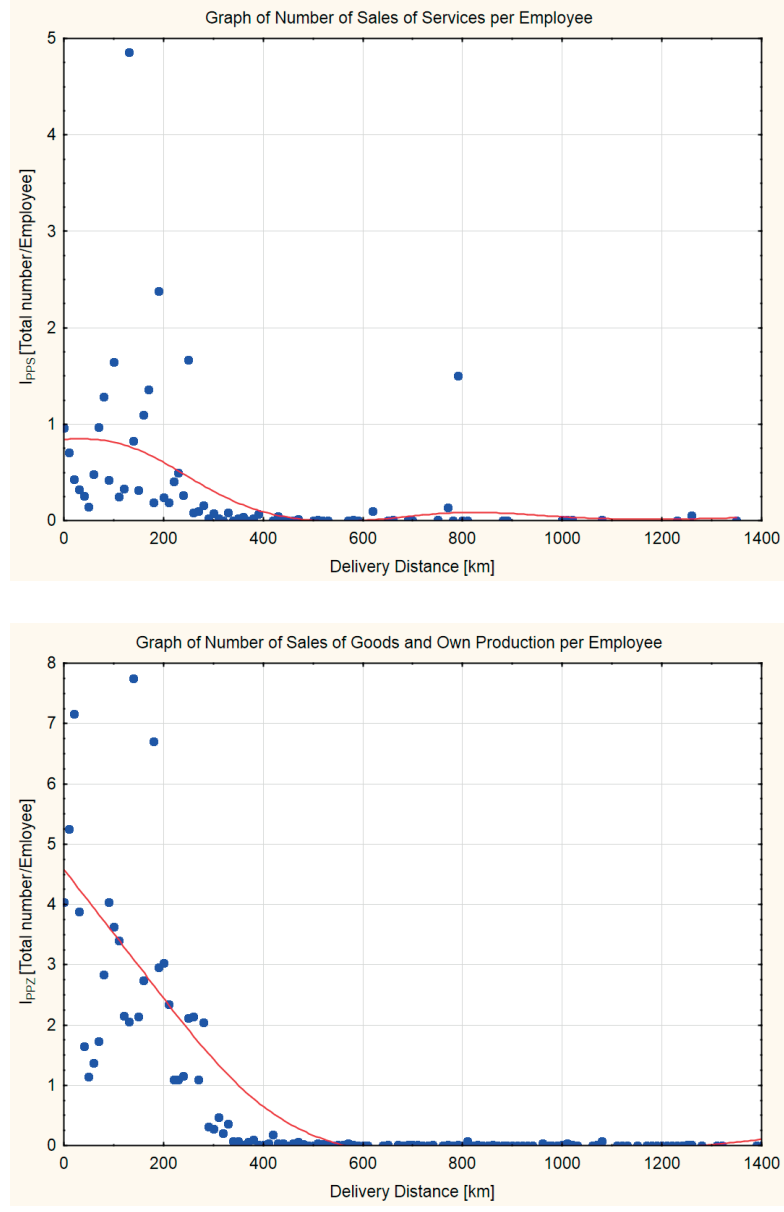

Figs. 6 and 7 Graph of number of sales of services per employee and year and of frequency of sales of goods and own production per employee and year (own source)
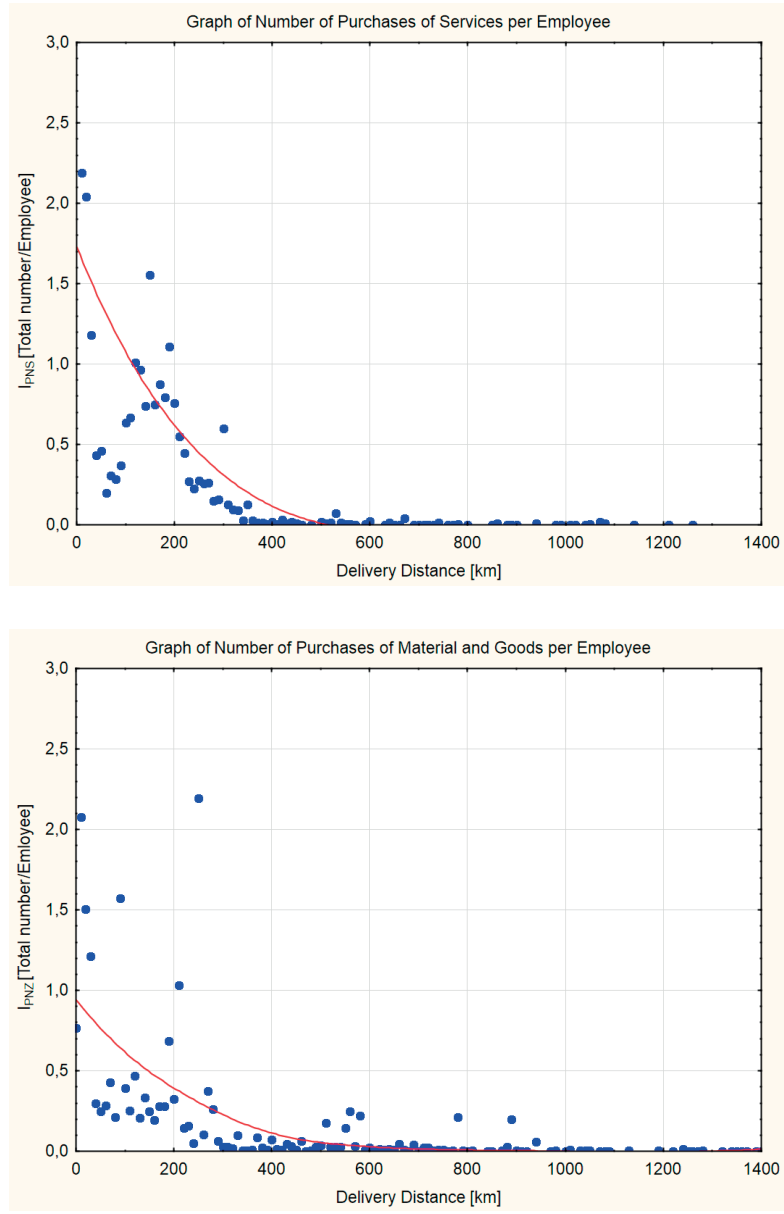

Figs. 8 and 9 Graph of number of purchases of services per employee and year and number of purchases of material and goods per employee and year (own source)

\section{Summary}

Research results deal with mutual geographical accessibility of economic units, which is indisputably an important aspect influencing the intensity and orientation of economic relations among them. We may observe that the interactive spatial relations between the individual spatial system elements based on the intensity of economic relations in business cases of business entities are directly proportional to the value of intensity of economic relations and indirectly proportional to their distance. Market proximity in general reduces the total costs of entrance to external markets; however, on the other hand, it usually represents larger competition in the market, which presses companies to higher productivity. From the business entity point of view the closeness of the market in the basic spatial framework represents the potential for market expansion. The shorter the mutual distance between individual units the higher the potential. In activities with more intensive cooperation in the manufacturing 
industry the aspect of market closeness is comparable with the aspect of the closeness of key customers. We have confirmed that accounting data enable mutual economic relations among the units to be identified and characterized despite the fact that the research data were only obtained from a limited number of business entities. The studies, dealing with various aspects of geographic economy, are gradually becoming an integral part of modern conceptions of logistics researches. They thus widen the system of economic theories, which was characterized by insufficient reflection of globalization processes, resulting from the idealized conception of lack of spatial dimensionality in the recent past. Increasing mutual dependence is a characteristic trait of global economy development. These phenomena may be described both by means of economic-logistic-statistical indicators obtained from statistic research, and by means of data from ERP systems, which bear a wide spectrum of information important for regional economy and development.

\section{References}

[1] SODOMKA, P., KLCOVA, H.: Information Systems in Business Practice. Brno : Computer Press, 2010. ISBN 978-80-251-2878-7.

[2] KOVANICOVA, D.: Financial Accounting: World Concept. Praha : Polygon, 2005. ISBN 80-7273-129-7.

[3] HANZAL, P.: The Calcucation of GDP of Regions and CR by The Production Method Through The Use of Accounting Data of Entepreneurial Units. Improforum. 2009, page 97-103.

[4] MAJCHRZAK, A, WANG, Q.: Breaking the Functional Mind-Set in Process Organization. Harward Business Review, SeptemberOctober, 1996.

[5] LIN,T., LIN, I.: Factors for Information Technology Acceptance Willingness and Adoption in Logistics Industry from Supply Chain Perspectives. Intern. J. of Electronic Business Management 2014, vol. 12, No. 3 pp. 167-177.

[6] GRABARA, J., KOLCUN, M.,KOT, S.: The Role of Information Systems in Transport Logistics. Intern. Journal of Education nad Research. 2014, vol.2, No. 2, ISSN 2201-6740

[7] BURDA, A.: Logistics Role in Economy, Knowledge-Economics, 2015, vol. 7, No. 1, pp. 170-173, ISSN 2066-1061

[8] NEDELEA, S.: Logistics in Knowledge Based Economy. Internal Auditing \& Risk Management, 2013, vol 8, No. 2,

[9] KETELS, C. H. M., MAMEDOVIC, O.: From Clusters to Cluster-based Economic Development. Intern. J. of Technological Learning, Innovation and Development. 2008, Sv. 1, 3/2008, pp. 375-392.

[10] PFOHL, H., MULLER, K.: Collaboration and Communication in a Networked Economy. LogForum, 2015, 11(2), pp. 139-149, ISSN 1734-459X

[11] MAJOCCHI, A., PRESUTTI, M.: Industrial Clusters, Entrepreneurial Culture and the Social Environment: The effects on FDI distribution. Intern. Business Review, vol. 18, No. 1, 2009, pp. 76-88.

[12] HUBER, F.: Social Capital of Economic Clusters: Towards a Network-based Conception of Social Resources. Tijdschrift voor economische en sociale geografie, vol. 100, No. 2, 2009, pp. 160-170.

[13] HE, J., FALLAH, M. H.: Is Inventor Network Structure a Predator of Cluster Evolution? Technological Forecasting \& Social Change, vol. 76, 2009, pp. 91-106.

[14] HENDERSON, J. V.: Cities and Development. J. of Regional Science, vol. 50, No. 1, 2010, pp. 515-540.

[15] FRENKEN, K., VAN OORT F., VERBURG T.: Related Variety, Unrelated Variety and Regional Economic Growth. Regional Studies, 41, 2007, pp. 685-697. ISSN 1360-0591.

[16] HOOVER, E. M.: The Location Theory and the Shoe and Leather Industries. Cambridge : Hardvard University Press, 1937.

[17] DICKEN, P., LLOYD, P. E.: Location in Space: Theoretical Perspectives in Economic Geography, 3, New York : Harper and Row, 1990. 